\title{
URGENSI PEMBANGUNAN KARAKTER BANGSA DALAM PERWUJUDAN KERUKUNAN ANTAR UMAT BERAGAMA
}

\author{
Hasmar Hussein \\ Mahasiswa Pascasarjana IAIN Padangsidimpuan \\ Jalan T. Rizal Nurdin KM. 4,5 Sihitang Padangsidimpuan \\ E-mail: hasmar24.08@gmail.com
}

\begin{abstract}
Abstrak
Indonesia adalah salah satu negara yang kaya akan keanekaragaman. Keanekaragaman tersebut meliputi agama, suku, bahasa, dan budaya. Pemerintah RI, sampai sekarang, telah mengakui 6 (enam) agama, yaitu Islam, Kristen, Katolik, Budha, Hindu, dan Konghuchu. Hal ini menunjukkan bahwa penduduk Indonesia tidak hanya menganut satu agama saja. Perbedaan agama yang dianut oleh penduduk Indonesia merupakan fakta yang menuntut terciptanya kerukunan. Salah satu cara dalam menciptakan kerukunan tersebut adalah dengan mengenal karakter bangsa itu sendiri. Pengenalan terhadap karakter bangsa yang utuh akan menimbulkan sikap kebersamaan, walaupun kebersamaan itu dibangun dari sebuah keragaman salah satunya keragaman dalam keyakinan.
\end{abstract}

\begin{abstract}
Indonesia is one country that is rich in diversity . Diversity includes religion, tribe, language, and culture. The Government of Indonesia has recognized 6 (six) religion until now, they are Islam, Christianity, Catholic, Buddhist, Hindu, and Confucian. It is indicates that the population of Indonesia is not only embrace one religion. Differences in religion professed by the Indonesian population is the fact that demands the creation of harmony. One way to create such harmony is to know the character of the nation itself. The introduction of the character of the whole nation will rise togetherness, although togetherness was built from a diversity of one of diversity in beliefs.
\end{abstract}

Kata Kunci: Karakter, Kerukunan, Agama 


\section{Pendahuluan}

Pembangunan karakter bangsa yang sudah diupayakan dengan berbagai bentuk, hingga saat ini belum terlaksana dengan optimal. Hal itu tercermin dari kesenjangan sosial, ekonomi, politik yang masih besar, kerusakan lingkungan yang terjadi di berbagai di seluruh pelosok negeri, masih terjadinya ketidakadilan hukum, pergaulan bebas dan pornografi yang terjadi di kalangan remaja, kekerasan dan kerusuhan, korupsi yang dan merambah pada semua sektor kehidupan masyarakat. Saat ini banyak dijumpai tindakan anarkis, konflik sosial, penuturan bahasa yang buruk dan tidak santun, dan ketidaktaatan berlalu lintas.

Masyarakat Indonesia yang terbiasa santun dalam berperilaku, melaksanakan musyawarah mufakat dalam menyelesaikan masalah, mempunyai kearifan lokal yang kaya dengan pluralitas, serta bersikap toleran dan gotong royong mulai cenderung berubah menjadi hegemoni kelompok-kelompok yang saling mengalahkan dan berperilaku tidak jujur.

Semua itu menegaskan bahwa terjadi ketidakpastian jati diri dan karakter bangsa yang bermuara pada:

1. Disorientasi dan belum dihayatinya nilai-nilai Pancasila sebagai filosofi dan ideologi bangsa.

2. Keterbatasan perangkat kebijakan terpadu dalam mewujudkan nilai-nilai esensi Pancasila.

3. Bergesernya nilai etika dalam kehidupan berbangsa dan bernegara.

4. Memudarnya kesadaran terhadap nilai-nilai budaya bangsa.

5. Ancaman disintegrasi bangsa.

6. Melemahnya kemandirian bangsa.

Kerukunan merupakan salah satu aspek yang mencirikan karakter bangsa Indonesia. Oleh karena itu, kerukunan yang menjadi bagian karakter bangsa harus diwujudkan serta diberlakukan dengan pemahaman serta penyikapan yang benar agar setiap masyarakat dapat bersatu, saling menghargai, dan bertoleransi untuk mewujudkan bangsa Indonesia yang maju dalam segala bidang. 


\section{Pembangunan Karakter Bangsa}

Untuk terwujudnya kerukunan dalam mayarakat Indonesia tidak terlepas dari pembentukan manusia cerdas. Pemaknaan kata cerdas bukan sekedar cerdas pengetahuan dan keterampilan, namun yang lebih penting dari itu adalah cerdas hati, cerdas pikir, cerdas raga, cerdas rasa, dan karsa, sehingga memiliki nilai-nilai luhur dan berbudaya. Artinya, manusia yang memiliki kecerdasan yang kompleks yaitu manusia yang berakhlak mulia, berbudi pekerti luhur, berbudaya, kreatif, inovatif serta yang berkarakter bangsa.

Karakter merupakan perpaduan yang tidak terpisahkan dari tiga hal yang berkaitan didalamnya yaitu moral, etika, dan akhlak. Moral lebih menitik beratkan pada kualitas perbuatan, tindakan atau tingkah laku manusia atau apakah perbuatan itu bisa dikatakan baik atau buruk, benar atau salah. Etika memberikan penilaian tentang baik dan buruk, berdasarkan norma-norma yang berlaku dalam masyarakat tertentu. Sedangkan akhlak tatanannya lebih menekankan bahwa pada hakikatnya dalam diri manusia itu telah tertanam suatu keyakinan bahwa keduanya (baik dan buruk) itu ada. ${ }^{1}$

Dapat disimpulkan bahwa karakter dapat diartikan sebagai nilai, budi pekerti, moral, watak, yang tujuannya mengembangkan kemampuan peserta didik untuk memberikan keputusan baik-buruk, memelihara yang baik itu, dan mewujudkan kebaikan itu dalam kehidupan sehari-hari dengan sepenuh hati.

Pemahaman karakter yang tidak dilandasi oleh prinsip tersebut akan menyebabkan warga masyarakat tercabut dari akar budaya. Ketika hal ini terjadi, maka bangsa hanya akan menghasilkan warga masyarakat yang tidak mengenal budayanya dengan baik, sehingga mereka menjadi orang "asing" dalam kehidupan kesehariannya.

Dengan demikian, perpaduan antara budaya dan karakter dapat dimaknai pula sebagai proses pendidikan yang secara aktif mengembangkan potensi warga melalui proses internalisasi dan penghayatan nilai-nilai yang menjadi kepribadian mereka dalam bergaul di

1Andaito (ed.), Atas Nama Agama. (Bandung: Pustaka Hidayah, 1998), h. 36. 
masyarakat dan mengembangkan kehidupan masyarakat yang lebih sejahtera serta kehidupan yang bermartabat yang dapat menjadi keunggulan bangsa di masa mendatang.

Pengembangan pembangunan budaya dan karakter harus dilakukan melalui perencanaan yang baik, pendekatan yang sesuai, metode belajar dan pembelajaran yang efektif. Sesuai dengan sifat suatu nilai, pembudayaan pendidikan budaya dan karakter bangsa hendaknya merupakan usaha bersama antara keluarga, sekolah, dan masyarakat.

Oleh karena itu, pengimplementasiannya perlu dilakukan secara bersama-sama dan senergi oleh semua pemangku kepentingan, terutama oleh satuan perangkat kerja daerah dan unsur-unsur yang berkaitan langsung melalui seluruh aktivitas kehidupan dalam masyarakat, dan senantiasa menjadi bagian yang tak terpisahkan dari budaya.

Dari pembahasan di atas bahwa pada saat ini pembangunan budaya dan karakter bangsa yang sarat dengan nilai, budi pekerti, moral, dan watak memang sangat diperlukan karena adanya kebutuhan nyata dan mendesak. Argumen tersebut tampaknya sangat relevan untuk membangkitkan komitmen dan melakukan gerakan nasional yang merupakan cerminan kebutuhan akan pendidikan nilai-nilai di Indonesia pada saat ini.

Urgensi dari pelaksanaan komitmen nasional pembangunan karakter, telah dinyatakan pada Sarasehan Nasional Pembangunan Budaya dan Karakter Bangsa sebagai Kesepakatan Nasional Pengembangan Pendidikan Budaya dan Karakter Bangsa, yang dibacakan pada akhir Sarasehan Nasional Tanggal 14 Januari 2010, sebagai berikut: "Pembangunan budaya dan karakter bangsa merupakan bagian integral yang tak terpisahkan dari pembangunan nasional secara utuh." 2

Pembangunan budaya dan karakter bangsa harus dikembangkan secara komprehensif sebagai proses pembudayaan. Oleh karena itu, pembangunan dan kebudayaan secara kelembagaan perlu diwadahi secara utuh. Pembangunan budaya dan karakter bangsa merupakan

2/bid, hlm. 38. 
tanggung jawab bersama antara pemerintah, masyarakat, sekolah dan orangtua. Oleh karena itu, pelaksanaan budaya dan karakter bangsa harus melibatkan keempat unsur tersebut.

\section{Agama sebagai Kelompok Etnis}

Secara terminologis, agama merupakan pedoman dasar untuk membuat pemeluknya hidup teratur sesuai dengan yang diajarkan agama. Agama merupakan seperangkat peraturan yang menata hubungan manusia dengan yang ghaib, manusia dengan manusia dan manusia dengan lingkungannya. Agama juga merupakan keyakinan yang dianut oleh suatu kelompok atau masyarakat yang menjadi norma yang diyakini. ${ }^{3}$

Landasannya adalah solidaritas dan toleransi yang inklusif. Solidaritas karena menyadari perlunya berhubungan baik dengan sesama manusia dan toleransi karena menyadari dalam menjalin hubungan itu ada perbedaan-perbedaan prinsip, keyakinan atau paham sebagai "kebenaran mutlak" yang dianut masing-masing orang.

Dengan demikian agama memberi etos spiritual yang amat besar, daya dan wilayah pengaruhnya bagi kehidupan dan kebudayaan manusia. Secara fungsional agama dimaksudkan sebagai suatu sikap hidup yang membuat orang mampu mengatasi kesulitan umat manusia, mampu memberikan jawaban dan memberi kepuasan spritual pada pertanyaan mendasar tentang teka-teki alam semesta dan peranan manusia di dalamnya, dengan memberkan ajaran praktis untuk hidup di alam semesta. ${ }^{4}$

Salah satu sifat dasar manusia adalah membutuhkan kehadiran manusia lainnya. Sifat ini menjadikan manusia cenderung untuk berkelompok ketika ia menemukan kesamaan tujuan, cita-cita, sifat dan sebagainya. Pengelompokan ini berlangsung dengan cepat ketika manusia mempunyai kesamaan agama, kebiasaan ataupun norma yang sama-

${ }^{3}$ Alo Liliweri, Gatra-Gatra Komunikasi Antarbudaya (Yogyakarta: Pustaka Pelajar, 2001), hIm. 255.

${ }^{4}$ A. Toynbee dan D. Ikeda, Perjuangan Hidup Sebuah Dialog, terjemahan Iskandar (Jakarta: Indera, 1976), hlm. 336. 
sama ditaati. Ketika sebuah kelompok sangat kokoh mempertahankan nilai-nilai kelompoknya maka kemungkinan orang lain untuk masuk ke dalam kelompok tersebut akan sulit. Kelompok ini menjadi ekslusif. ${ }^{5}$ Inilah sifat dasar kelompok etnik, yakni menjaga dan mempertahankan normanorma yang dianut.

Kelompok agama adalah sekumpulan manusia yang berkelompok berdasarkan keyakinan, kepercayaan, iman terhadap sesuatu yang dianggap sakral. Anggota kelompok dengan kuat mempertahankan sistem nilai dan kepercayaan yang mereka yakini. Terdapat persamaan mendasar antara kelompok agama dengan kelompok etnis. Karena itu kelompok agama bisa dipandang sebagai bagian dari kelompok etnis.

Ada beberapa alasan mengapa kelompok agama eksis dan diakui oleh masyarakat, antara lain:

a. Kelompok agama mempunyai anggota dengan jumlah tertentu dan mampu berkembang baik sistem nilai dan keyakinan yang dianut ataupun jumlah anggota kelompok.

b. Diakui oleh masyarakat karena tidak membawa dampak disintegrasi.

c. Mempunyai kesamaan nilai dan keyakinan yang secara sadar diamalkan dan diakui oleh kelompok lain.

d. Membentuk jaringan komunikasi intrakelompok yang berbeda dengan kelompok lain.

e. Mempunyai ciri yang berbeda dengan kelompok lain. ${ }^{6}$

\section{Kerukunan Antar Umat Beragama}

Dunia keagamaan manusia menampilkan fenomena kemajemukan. Kemajemukan agama adalah kenyataan yang tidak dapat dipungkiri, mungkin merupakan sunnatullah dalam proses pembiakan dan penyebaran umat manusia. Realitas kemajemukan dan pemajemukan, di satu sisi

${ }^{5}$ Alo Liliweri, Gatra-Gatra Komunikasi, hlm, 255.

${ }^{6}$ Robert N. Bellah, Beyond Belief, Esei-Esei Tentang Agama di Dunia Modern, Menemukan Kembali Agama, Terjemahan Rudy Harisyah Alam. (Jakarta: Paramadina, 2000), hlm. 134. 
merupakan mosaik yang indah, namun di sisi lain merupakan tantangan bagi dunia keagamaan.

Hal ini disebabkan karena kemajemukan itu mengandung potensi konflik. Kendati agama memiliki kekuatan pemersatu, agama juga mempunyai potensi pemecah belah. Kesan ambivalensi agama salah satunya dapat dilihat dari fenomena perang dan damai, sebagai akibat logis dari watak-watak agama yang dapat mendorong pertentangan dan konflik. Watak-watak itu antara lain adalah watak penyebaran agama (ekspansionisme). Pertautan antara kedua watak ini merupakan faktor pemicu dan pemacu konflik antar umat beragama. ${ }^{7}$

Agama pada hakekatnya adalah refleksi dan manifestasi dari penyerahan manusia terhadap kekuatan yang Maha Luar Biasa dan keterbatasan rasio manusia dalam memahami realitas serba kompleks tapi terintegrasi secara sempurna. Agama merupakan semesta simbolik yang memberi makna pada kehidupan manusia dan memberikan penjelasan yang paling komperehensif tentang realitas seperti kematian, penderitaan, tragedi dan ketidakadilan. Agama juga merupakan kanopi (tirai) sakral yang melindungi manusia dari chaos (ketidateraturan). ${ }^{8}$

Kultur masyarakat Indonesia sebagaimana digambarkan oleh Denny J.A. bersifat konfliktual, yang tergambar dari sejarah konflik komunal yang panjang (Islam versus Kristen, pribumi versus non-pribumi, pendatang versus penduduk asli). ${ }^{9}$ Jadi dalam dinamika kehidupan masyarakat yang pluralis seperti Indonesia, yang dibutuhkan adalah keterbukaan sikap dan pemikiran. Sebagaimana keanekaragaman budaya dan etnis yang diakui dan diutamakan dalam semboyan negara "Bhinneka Tunggal Ika" (Diversity in Unity), namun dalam kenyataannya yang ditekankan adalah "kesatuan" bukan "keanekaragaman". Padahal kalau yang ditonjolkan adalah "keanekaragaman", barangkali akan lebih menggambarkan realitas

${ }^{7}$ lbid., hlm. 148.

8/bid., hlm. 149.

9Denny A.J., "Problem Demokrasi di Indonesia", Makalah Workshop for Lecture on Civic Education diselenggarakan oleh ICCE IAIN Syarif Hidayatullah Jakarta, Bogor, 6-18 Agustus 2001, hlm. 2. 
yang sesungguhnya. "Keanekaragaman dan kesatuan" merupakan mosaik dari perwjudan dari civil society, sebagaimana yang diinginkan oleh banyak orang Indonesia. 10

Dalam konteks masyarakat yang plural seperti Indonesia misalnya, kebhinnekaan secara kultural maupun keagamaan akan dapat terus dipelihara dengan konsensus umum mengenai nilai dan norma yang dihormati bersama. la tidak harus tunduk pada formulasi doktrinal, apalagi menuruti salah satu agama. Itulah sebabnya "civil religion" atau "social ethnics" perlu dikembangkan oleh para pemeluk agama. Olaf Schumann mengatakan bahwa konsep civil religion dengan memisahkan organisasi keagamaan dan organisasi negara dari ghetto pelembagaan yang membuatnya tunduk pada kepentingan lain, sehingga agama-agama bebas untuk menentukan sendiri bagaimana cita-citanya yang berkaitan dengan kehidupan sosial yang dapat dibawahkan dalam suatu dialog sosial dengan golongan lain. ${ }^{11}$

Konsepsi kerukunan dalam keanekaragaman penganut agama di Indonesia telah lama menjadi perbincangan yang hanya. Secara historis, istilah kerukunan hidup beragama pertamakali muncul dalam pidato Menteri Agama K.H.M. Dachlan pada pembukaan Musyawarah Antar Agama, 30 November 1967 yang berlangsung di Gedung Dewan Perimbangan Agung (DPA) Jakarta. Musyawarah itu dihadiri pemuka agama Islam, Kristen, Katolik, Hindu dan Budha. Sejak masa itulah, kerukunan hidup beragama digunakan dalam berbagai wacana peraturan perundang-undangan, GBHN, dan program-program pemerintah. ${ }^{12}$

Makna kerukunan hidup umat beragama adalah perihal hidup rukun yaitu hidup dalam suasana baik dan damai, bersatu hati dan bersepakat antar umat yang berbeda-beda agama atau antara umat dalam satu

10/bid., hlm. 4.

${ }^{11}$ Olaf Schumann, "Kata Pengantar", dalam Robert N. Bellah, Beyond Belief, EseiEsei Tentang Agama di Dunia Modern, Menemukan Kembali Agama, Terjemahan Rudy Harisyah Alam (Jakarta: Paramadina, 2000), hlm. xxvi.

12Lembaga Informasi Nasional, Kerukunan Hidup Umat Beragama (Jakarta: Lembaga Informasi Nasional, 2001), hlm. 1. 
agama. Dalam terminologi yang digunakan pemerintah selama ini, konsep kerukunan hidup umat beragama mencakup 3 (tiga) hal, yaitu:

1. Kerukunan intern umat beragama

2. Kerukunan antar umat yang berbeda-beda agama

3. Kerukunan antara (pemuka) umat beragama dengan pemerintah. ${ }^{13}$

Secara teologis, masing-masing agama menghendaki umatnya untuk memelihara kerukunan dan harus menempatkan hubungan antar sesama manusia sebagai inti manifestasi iman dan hidup berketuhanan. Hanya saja timbul persoalan, bagaimana mewujudkankannya dalam kehidupan sehari-hari. Untuk mewujudkannya diperlukan adanya pemahaman dari masing-masing individu sebagai umat beriman, sehingga setiap saat dapat dioperasaionalisasikan di tengah-tengah masyarakat lingkungannya. Kerukunan harus wujud dalam keseimbangan yang dinamis, yakni kebebasan beragama yang tidak merusak kerukunan, tetapi sebaliknya kerukunan juga tidak mematikan kebebasan beragama. Implementasi nilai-nilai ajaran tentang kerukunan itu harus secara otentik tampak dalam prilkau masyarakat, sehingga kerukunan dapat berjalan secara dinamis dan tebuka sebagai refleksi dari ajaran setiap agama.

Pembahasan mengenai hubungan antar agama dengan demikian memiliki dua aspek penting:

a. Berhubungan dengan doktrin agama.

b. Aspek yang berhubungan dengan umat beragama. ${ }^{14}$

Kedua aspek ini dalam kajiannya tidak dapat dipisahkan sebab doktrin agama menjadi sumber dan penyikapan manusia beragama. Inti persoalannya terletak pada umat beragama. Sehingga dalam pembicaraan hubungan antar agama paling tidak ada tiga pendekatan yang dapat digunakan, yakni pendekatan teologis, politis dan budaya (antropologis). Ketiga pendekatan ini, satu sama lain saling mempengaruhi, dan akan terlihat manakala kita mengkaji satu obejk masyarakat beragama.

Pendekatan teologi mengkaji hubungan antar agama berdasarkan sudut pandang ajaran agamanya masing-masing, yaitu cara doktrin-doktrin

13/bid, hlm. 2.

14 /bid., hlm. 44. 
agama menyikapi dan berbicara tentang agamanya dan agama orang lain. Pendekatan teoritis melalui analasis politis dilihat dalam konteks kerukunan dengan maksud melihat masing-masing penganut agama dalam memelihara ketertiban, kerukunan dan stabilitas suatu masyarakat yang multiagama. Adapun pendekatan kultur atau budaya adalah meilhat dan memahami karakteristik suatu masyarakat yang lebih menitiberatkan aspek tradisi yang berkembang dan mapan, yaitu agama yang dihormati sebagau sesuatu yang luhur dan sakral yang dimiliki oleh setiap mansia atau masyarakat. ${ }^{15}$

Frithjof Schuon melihat hubungan antar agama sebagai watak asli manusia beragama, karena agama-agama yang ada merupakan wujud konkret dari satu Tuhan. ${ }^{16} \mathrm{Di}$ Indonesia, teori yang diajukan oleh para agamawan (juga cendikiawan) terbatas pada 2 (dua) aspek, yaitu:

a. Konsep kerukunan, yakni pemaparan teoritis tiap-tiap agama.

b. Aspek dialog antar cendekiawan yang diwujudkan dalam bentuk hubungan antar lembaga formal. Akan tetapi, hubungan antar lembaga formal ini harus bersifat seremonial, belum pada tataran konseptual. ${ }^{17}$

\section{Urgensi Pembangunan Karakter Bangsa dalam Perwujudan Kerukunan Antar Umat Beragama}

Pembangunan karakter bangsa dalam perwujudan kerukunan antar umat beragama yang selama ini dilaksanakan telah menunjukkan kemajuan di berbagai bidang kehidupan masyarakat, yang meliputi bidang sosial budaya dan kehidupan beragama, ekonomi, ilmu pengetahuan dan teknologi, politik, pertahanan dan keamanan, hukum dan aparatur, pembangunan wilayah dan tata ruang, penyediaan sarana dan prasarana, serta pengelolaan sumber daya alam dan lingkungan hidup. Namun, di samping banyak kemajuan yang telah dicapai ternyata masih banyak

\footnotetext{
${ }^{15}$ Adeng Muchtar Ghazali, Agama dan Keberagaman dalam Konteks Perbandingan Agama (Bandung: Pustaka Setia, 2004), hlm. 13.

16Frithjof Schuon, Islam dan Filsafat Perennial, terjemahan Rahmani Astuti (Bandung: Mizan, 1993), hlm. 57.

17 /bid., hlm. 60.
} 
masalah dan tantangan yang belum sepenuhnya terselesaikan, termasuk kondisi karakter bangsa yang akhir-akhir ini mengalami pergeseran.

Pembangunan karakter bangsa yang sudah diupayakan dengan berbagai bentuk, hingga saat ini belum terlaksana dengan optimal. Hal itu tecermin dari kesenjangan sosial-ekonomi-politik yang masih besar, kerusakan lingkungan yang terjadi di berbagai di seluruh pelosok negeri, masih terjadinya ketidakadilan hukum, pergaulan bebas dan pornografi yang terjadi di kalangan remaja, kekerasan dan kerusuhan, korupsi yang dan merambah pada semua sektor kehidupan masyarakat.

Semua itu menegaskan bahwa terjadi ketidakpastian jati diri dan karakter bangsa yang bermuara pada:

1. Disorientasi dan belum dihayatinya nilai-nilai Pancasila sebagai filosofi dan ideologi bangsa

2. Keterbatasan perangkat kebijakan terpadu dalam mewujudkan nilai-nilai esensi Pancasila.

3. Bergesernya nilai etika dalam kehidupan berbangsa dan bernegara.

4. Memudarnya kesadaran terhadap nilai-nilai budaya bangsa.

5. Ancaman disintegrasi bangsa

6. Melemahnya kemandirian bangsa. ${ }^{18}$

Sebagaimana tercantum dalam Rencana Pembangunan Jangka Panjang Nasional Tahun 2005 - 2025 (Undang-Undang Republik Indonesia Nomor 17 Tahun 2007), yaitu terwujudnya karakter bangsa yang tangguh, kompetitif, berakhlak mulia, dan bermoral berdasarkan Pancasila, yang dicirikan dengan watak dan prilaku manusia dan masyarakat Indonesia yang beragam, beriman dan bertakwa kepada Tuhan Yang Maha Esa, berbudi luhur, bertoleran, bergotongroyong, berjiwa patriotik, berkembang dinamis, dan berorientasi iptek. ${ }^{19}$

Pembangunan karakter bangsa memiliki urgensi yang sangat luas dan bersifat multidimensional termasuk dalam hal kerukunan antar umat beragama, karena terkait dengan pengembangan multiaspek potensi-

18 Dadang Kahmad, Sosiologi Agama.(Bandung: Remaja Rosdakarya, 2000), hlm. 46.

19/bid., hlm. 48-49. 
potensi keunggulan bangsa dan bersifat multidimensional karena mencakup dimensi-dimensi kebangsaan yang hingga saat ini sedang dalam proses "menjadi". Dalam hal ini dapat juga disebutkan bahwa:

1. Karakter merupakan hal sangat esensial dalam berbangsa dan bernegara, hilangnya karakter akan menyebabkan hilangnya generasi penerus bangsa.

2. Karakter berperan sebagai "kemudi" dan kekuatan sehingga bangsa ini tidak terombang-ambing.

3. Karakter tidak datang dengan sendirinya, tetapi harus dibangun dan dibentuk untuk menjadi bangsa yang bermartabat. ${ }^{20}$

Selanjutnya, pembangunan karakter bangsa akan mengerucut pada 3 (tiga) tataran besar, yaitu:

1. Untuk menumbuhkan dan memperkuat jati diri bangsa.

2. Untuk menjaga keutuhan Negara Kesatuan Republik Indonesia (NKRI).

3. Untuk membentuk manusia dan masyarakat Indonesia yang berakhlak mulia dan bangsa yang bermartabat. ${ }^{21}$

Pembangunan karakter bangsa harus diaktualisasikan secara nyata dalam bentuk aksi nasional dalam rangka memantapkan landasan spiritual, moral, dan etika pembangunan bangsa sebagai upaya untuk menjaga jati diri bangsa dan memperkukuh persatuan dan kesatuan bangsa dalam naungan NKRI sehingga melahirkan kerukunan antar umat beragama yang bersifat kuat dan bersatu.

Pembangunan karakter bangsa harus dilakukan melalui pendekatan sistematik dan integratif dengan melibatkan keluarga, satuan pendidikan; pemerintah, masyarakat termasuk teman sebaya, generasi muda, lanjut usia, media massa, pramuka, organisasi kemasyarakatan, organisasi politik, organisasi profesi, lembaga swadaya masyarakat, kelompok strategis seperti elite struktural, elit politik, wartawan, budayawan, agamawan, tokoh adat, serta tokoh masyarakat.

20Adeng Muchtar Ghazali, Agama dan Keberagaman dalam Konteks Perbandingan Agama, ...., hlm. 23.

21/bid., hlm. 26. 
Adapun strategi pembangunan karakter dapat dilakukan melalui sosialisasi, pendidikan, pemberdayaan, pembudayaan, dan kerja sama dengan memperhatikan kondisi lingkungan dan kebutuhan masyarakat serta pendekatan multidisiplin yang tidak menekankan pada indoktrinasi.

Dalam rangka meningkatkan pembangunan karakter yang berhasil guna, diperlukan upaya-upaya nyata antara lain penyusunan desain pembangunan karakter secara nasional, penyusunan rencana aksi nasional secara terpadu, pencanangan pembangunan karakter bangsa oleh Presiden Republik Indonesia sebagai tonggak dimulainya revitalisasi pembangunan karakter bangsa, serta implementasi pembangunan karakter oleh semua komponen bangsa dan aktualisasi nilai-nilai karakter secara nyata dalam kehidupan berbangsa dan bernegara.

\section{Penutup}

Pembangunan karakter bangsa sangat urgen untuk dilaksanakan karena selain menumbuhkan dan memperkuat jati diri bangsa, menjaga keutuhan Negara Kesatuan Republik Indonesia (NKRI) dan membentuk manusia dan masyarakat Indonesia yang berakhlak mulia dan bangsa yang bermartabat.

Konsep kerukunan hidup umat beragama mencakup 3 (tiga) hal, yaitu: kerukunan intern umat beragama, kerukunan antar umat yang berbeda-beda agama, dan kerukunan antara (pemuka) umat beragama dengan pemerintah. Urgensi pembangunan karakter bangsa dalam mewujudkan kerukunan antar umat beragama terlihat dari: pertama, jika suatu masyarakat dibangun berdasarkan karakter kebangsaan maka akan terjadi kerukunan antar umat beragama; kedua, pemahaman karakter bangsa yang sesuai dengan UUD 1945 dan Pancasila akan mewujudkan persatuan dan kesatuan yang tidak mengedepankan aspek suku ras maupun agama.

\section{Daftar pustaka}

Adeng Muchtar Ghazali, Agama dan Keberagaman dalam Konteks Perbandingan Agama, Bandung: Pustaka Setia, 2004. 
Hasmar Hussein

Alo Liliweri, Gatra-Gatra Komunikasi Antarbudaya, Yogyakarta: Pustaka Pelajar, 2001.

Andaito (ed.), Atas Nama Agama, Bandung: Pustaka Hidayah, 1998.

A. Toynbee dan D. Ikeda, Perjuangan Hidup Sebuah Dialog, terjemahan Iskandar, Jakarta: Indera, 1976.

Dadang Kahmad, Sosiologi Agama, Bandung: Remaja Rosdakarya, 2000.

Frithjof Schuon, Islam dan Filsafat Perennial, terjemahan Rahmani Astuti, Bandung: Mizan, 1993.

Robert N. Bellah, Beyond Belief, Esei-Esei tentang Agama di Dunia Modern, Menemukan Kembali Agama, Terjemahan Rudy Harisyah Alam, Jakarta: Paramadina, 2000. 